\title{
"Meaningful service": pedagogy at Israeli pre-military academies and the ethics of militarism
}

This article examines the intersections between militarism and ethics through a study of pedagogy at Israeli pre-military academies [mechinot kdam tzva'iyot $].{ }^{1}$ It argues that it is possible for ethics to function as a militarist activity which, rather than limiting the use of violence, is in fact an enabling factor in the resort to force. This argument is made on the theoretical premise that ethics should be analysed as a practice of subject formation in which individuals engage in practices of self-fashioning through self-directed work upon themselves. When this takes place in a military context, or in pursuit of military goals, ethics can quite easily become part of a powerful militarist process which binds individual subjectivities and selfexperience to military participation. I argue that the observation of this relationship in practice in Israel should prompt a re-evaluation of the concept of militarism, and of the capacity of ethics to constrain military violence.

Israel has long been studied as an example of societal militarism (Kimmerling, 1993; BenEliezer, 1998; Lomsky-Feder and Ben-Ari, 1999; Maman, Ben-Ari, and Rosenhek, 2001; Levy, 2007; Sheffer and Barak, 2010). Moreover, its significance as a leading practitioner of counterinsurgency, and as a node in the global circulation of military and security technologies and practice more generally, recommends it as an important and influential case (Graham, 2010; Gordon, 2010; Gregory, 2004; Khalili, 2010). I have chosen to concentrate on pre-military academies firstly because they are institutions which localise a highly condensed form of the intersections between ethics and militarism that I wish to examine, but also because they are an understudied but increasingly important feature of military service in Israel. These academies have rapidly expanded in recent years, with more than 3,300 high school graduates now 
attending them each year. Moreover, they consistently send a high proportion of their graduates to combat units and to officer courses.

This article is based on original fieldwork conducted by the author comprising interviews with staff at these academies, participant-observation during visits to academies, and other primary materials. ${ }^{2}$ Analysing their overall educational approach and specific pedagogical strategies, I argue that it is a common emphasis on ethics which primarily underpins their contribution to militarism. I will show that a key feature of pedagogy at mechinot is preparation for "meaningful service" in the IDF through practices of ethical self-cultivation. Indeed, practices at these academies exemplify a wider culture of militarism in which military participation is imbued with an ideology of ethical soldiering.

I begin by outlining a theory of the connection between militarism, ethics, and subject formation which develops existing scholarship on the nature of militarism. I then situate this argument in relation to Israeli pre-military academies and place it in the context of existing studies of the military and militarism in Israel. I then offer an overview of Israeli pre-military academies and their influence on the IDF. Subsequently, in the main empirical section, I substantiate my arguments by discussing the pedagogical approach and ethical emphasis of pre-military academies. I firstly observe the widespread emphasis on ethical self-cultivation. Secondly, I analyse the teaching of military ethics, observing the inculcation of the desire to be an ethical soldier and analysing various strategies for the ideological legitimation of violence. Finally, I argue that pre-military academies present military service as an ethical "test of the self", highlighting the theme of purity. Together, these elements produce an ideology of ethical soldiering and "meaningful service" which strengthens Israeli militarism by combining military participation with a project of personal ethical improvement. 


\section{Militarism, ethics, and subject formation}

How can ethics be a militarist practice? Ethics and war are often intuitively imagined as a kind of antagonistic pair, in which greater emphasis on one necessarily comes at the expense of the other. Ethics is therefore commonly conceived as a possible effective limit on war which might constrain its occurrence and excesses. However, this relationship is far from automatic. Rather, it is an assumption based on a certain simplistic understanding of ethics as an active set of norms, norms often imagined as pacifistic or non-violent. Before being able to account for the links between ethics and militarism, therefore, a clearer concept of ethics is needed which is grounded in relevant social theory.

Ethics is often equated with morality, but this is a matter of controversy. Acknowledging these disagreements, many scholars either opt to leave this question open or decide that their interchangeable usage prevents any consistent distinction between them (cf. Fassin, 2012: 5-6; Hutchings, 2010: 7-8). In this article, however, I adopt the position that ethics and morality are at least analytically separable, even if in practice they are often inextricable. In this, I am following the theoretical innovations made in the anthropology of ethics, where this distinction is central (Faubion 2012; Fassin, 2012: 6-7; Laidlaw, 2013: 110-119). For the purposes of what follows, morality is the domain concerned with determining and achieving the good. Ethics, by contrast, is a set of practices carried out by the self on the self which are aimed at enabling the subject to behave effectively in a certain way. Put more succinctly, while ethics often concerns morality, most fundamentally it should be understood as a practice of subject formation.

The theorist who has done the most to explicate this point is Michel Foucault, whose later work on ethics emphasises practices of subjectivation over the moral content of a normative system or the actual moral behaviour of individuals (1998, 2000a). In his study of ancient sexuality, for example, Foucault's focus is not on the set of normative prohibitions which operated in Greek or 
Roman society or on how far these were observed. Rather, he draws attention to the ways in which subjects attempted to cultivate themselves as sexual beings through careful regimens of diet, exercise, and study. Likewise, many anthropological studies have drawn on Foucault's theory to study the formation of subjects, and especially pious subjects, through ethical practice (e.g. Hirschkind, 2006; Mahmood, 2006).

Viewed from the perspective of subject formation, there is no a priori reason why the telos of ethical practice cannot be preparation for participation in war. Indeed, it is perfectly possible to imagine a set of ethical practices which would be aimed at producing, not a sexual subject, or a pious subject, but a soldier-subject. It is at this point that ethics can converge with military goals. Indeed, existing studies of military ethics education, which have primarily focussed on assisting practitioners, note the contribution that ethical pedagogy makes to military effectiveness (Robinson, de Lee, and Carrick, 2008; Carrick, Connelly, and Robinson, 2009). They have conceived of military ethics as central to military training and the professional development of soldiers. Scholars have also argued that military ethics can make a moral contribution beyond this. Distinguishing between "functional" and "aspirational" approaches, Wolfendale argues that the latter model also prioritises the development of soldiers' autonomous "moral character" as "virtuous people" (2008: 161; see also, Berghaus and Cartagena, 2013). However, this distinction assumes that the only "functional" contribution ethics makes is in ensuring "correct behaviour" (165). In fact, as I will show, military ethics education can also make significant ideological and motivational contributions to war-fighting and war-preparation beyond simply ensuring soldiers' compliance and effectiveness. This makes it much harder to distinguish between the "functional" and "aspirational" dimensions of military ethics than Wolfendale allows. To grasp this, ethics must be understood as a facet not just of the military profession, but of militarism. 
Militarism is undergoing a revival as concept in the field of International Relations. Stavrianakis and Selby (2013: 3-18) identify five central definitions of the concept - as ideology, as a behavioural phenomenon, as military build-up, as a set of institutional relationships, as a sociological process - preferring the sociological version developed by Shaw. For Shaw (1991, 2013), militarism denotes "the penetration of social relations by military relations", describing a situation where war-making and war-preparation come to determine other social activities (such as economic production, popular culture, or gender relations). This sociological view of militarism has been enormously productive in charting the military significance of an array of social practices not normally studied as artefacts of war-making. Indeed, it has reconfigured our understanding of the boundaries of "the military" itself, moving scholars away from studying its formal institutional locale in "civil-military relations" and towards an appreciation of the thicker social field in which war takes place.

This prompts a reconceptualisation of earlier definitions of militarism, such as the following formulation offered by Klare: “[militarism is] the tendency of a nation's military apparatus ... to assume ever-increasing control over the lives and behaviour of its citizens (1980: 36, emphasis in original) This "military apparatus" should no longer be considered a discrete institutional stratum which imposes its way of thinking on society. Instead, this "apparatus" should be understood in its full Foucauldian sense as a dispositif, as a mechanism of power which transcends any particular set of institutions and takes hold of individual subjectivities through a wider array of quotidian social relations (Foucault, 1979, 195-228; 1980, 194-209; 2006: 63-91). Militarism is, in short, a form of governmentality, one which not only operates on subjects, but also produces them (Foucault, 2002a).

Understanding militarism therefore requires an analysis of the ways in which subjects are made warlike through social practice. For feminist scholars, understanding militarism as subject formation in this way has been a long-standing objective. Cynthia Enloe (2000) has shown the 
ways in which subjects are produced and coded as masculine or feminine depending on their differential participation in war. She and other scholars have demonstrated that gendered subject formation is essential to the perpetuation of militarism (Enloe, 2007; Segal, 2008; Sjoberg and Via, 2010). Relevantly for this article, several feminist studies have shown the importance of educational settings for the propagation of gender norms which strengthen militarism and undermine possible resistance to it (Altınay, 2004: esp. 117-157; Conway, 2012: esp. 56-85). Likewise, Elshtain's classic study of military ethical discourse argues that the principal paradigm for considering the role of ethics in war, "Just War Theory", rests on an inherently masculinist discourse which is concerned with producing the male soldier as a "just warrior" and domesticating the female civilian as a "beautiful soul" (1995; see also, Sjoberg, 2006; Owens, 2010).

I argue that this feminist sensitivity to processes of subject formation in militarism needs to be extended to incorporate wider practices of subjectivation, not least the role of ethical selffashioning. Following Foucault, I view ethics as a crucial component of governmentality. If governmentality is an exercise in "the conduct of conduct" (Foucault 2008a: esp. 87-114), whereby a close management of individual behaviour becomes the decisive intervention in the exercise of power, ethics, in which subjects direct their own conduct through self-cultivation, thus acquires great significance in the functioning of power relations (Foucault, 2000b; 2005: 251-252). The promotion or direction by militaries of ethical activity should accordingly be interpreted as an aspect of the production of militarist governmentality.

Foucauldian studies of contemporary liberal militarism have tended to interpret it as a form of biopolitics, in which the imperative to "make life live" is guaranteed by the use of violence to eliminate threats to the population (Dillon and Neal, 2008; Evans, 2010; Morton and Bygrave, 2008; Reid, 2006; Reid and Dillon, 2009). This has been combined with an emphasis on the role of disciplinary techniques and embodied practice in the shaping of soldiers as agents of this 
biopolitical project (Higate, 2012; McSorley, 2013). Militaries are accordingly understood as disciplinary structures par excellence whose function is to produce "docile bodies" capable of exercising state violence. Through careful training, processes of surveillance, and drilling, these soldier-bodies become the object of an intense "anatamo-politics" in which movements and emotions are carefully controlled. Such processes also acquire powerful gendered, racial, and class dimensions which layer identities with military significance (Basham, 2013).

Yet it is also necessary to combine this biopolitical and anatamo-political perspective on militarism with a focus on the role of ethical conduct. This requires attention not only to the production of soldier-populations and soldier-bodies but also to the formation of solider-subjects. Scholars of governmentality have observed the ways in which, especially in neo-liberal forms of government, individuals are made "subjects of their lives" (Burchell, 1996: 29-30) through the promotion of value systems and a culture of freedom in which they are made responsible for conducting themselves (Dean, 2010: 19-21, 26-27; Foucault, 2008b; Rose, 1996, 1999). This greater margin for freedom in the conduct of individuals has increased the prominence of ethics as a component of liberal modes of government - and militaries have not been exempt from these trends. Understanding militarism as a form of governmentality requires attention to these micro-practices of ethics as well as to interventions at the level of populations or bodies, necessitating an examination of the relationship between ethics as a "technology of the self" and militarism as a "political technology of individuals" (Foucault, 2002b; 2000c). It is only by considering processes of ethical subject formation that the full contribution of pre-military academies to Israeli militarism can be adequately comprehended.

\section{The ethics of Israeli militarism}

Recent studies of Israeli militarism develop a strongly sociological account, emphasising the distribution of symbolic and material rewards to different sectors of the population through 
participation in military service (Levy, 1997, 2007; Sheffer and Barak, 2010). The main development which such scholars have sought to explain is the decline of a hegemonic pact between the secular $a s h k e n a z i^{3}$ elite and the military, and its replacement with a reliance on a more diverse population (Levy, 2007: 117-125, 229-236; Levy, Lomsky-Feder, and Harel, 2007). In particular, scholars have emphasised the growing presence of national-religious soldiers in the army and the changing institutional arrangements made to accommodate them (Cohen, 2013; Levy, 2014; Rosman-Stollman, 2014). As the traditional ashkenazi elite has proven less willing to make sacrifices on the altar of the national-security state, this account proceeds, they have been replaced with a more ideologically driven group of national-religious soldiers. Such analyses often raise the prospect that this may generate tension and division in the ranks and constrain the ability of the military to implement controversial policies, especially with respect to the evacuation of Israeli settlements (Cohen, 2013; Levy, 2014). It has also been argued that national-religious soldiers are more willing to use violence against Palestinians, and have fewer qualms about hurting civilians (Lebel, 2013).

In keeping with this emphasis, pre-military academies are usually presented as institutions facilitating the entrance of national-religious soldiers into the ranks (Cohen, 2013: 11-12, 70-71, 89, 92, 104, 134 [n. 6]; Levy, 2014: 277-281, 285, 287; Rosman-Stollman, 2014: 104-123). However, a focus on the role of militarism in the reproduction of social hierarchies does not capture the full extent of the mechanisms being used to encourage military participation. Moreover, it has meant that the role of secular academies has been downplayed and their commonalities with religious academies overlooked. This has also had the effect of portraying secular academies as somehow less militaristic than their religious counter-parts, in keeping with a wider discourse on the religious/secular divide in Israel in which "extreme" religious elements are accorded primary responsibility for the worst excesses of the Israeli State (Dalsheim, 2012). 
Instead, the growth of pre-military academies calls our attention to another feature of Israeli militarism, which is its growing intersection with ethical practice. This new ethics of Israeli militarism may be practiced differently in secular and religious pre-military academies; but its contribution is profound in both cases. There are two principal ways in which ethics serves a militarist purpose in pre-military academies. Firstly, these academies present military service as an opportunity for self-cultivation. Participation in war thereby becomes a means to improve and test one's ethical character. Militarism consists in the way that soldiers are able to attach an individual project of self-improvement to a national, colonial project of military activity. Existing studies of Israeli militarism in a range of contexts have emphasised how military participation is crucial for the consolidation of gendered identities (Sasson-Levy, 2002, 2003a, 2008), racial hierarchies (Sasson-Levy, 2003b), and notions of citizenship (Helman, 1997). In this article, I show how such processes of consolidation are also ethical, in that the production of collective identities is both achieved and valorised through the individual ethical work of the subject.

Secondly, through the incorporation of military ethics into their curricula, these academies ideologically legitimate violence through pedagogical strategies of moralisation, depoliticisation, and abstraction. It is important to be clear that this emphasis on military ethics is not aimed at the reduction of the level of violence used against Palestinians. Rather, it is tailored to produce graduates imbued with a sense of their ethical mission as soldiers. Indeed, military ethics is used to promote this ideological belief alongside the enormous violence wielded by the IDF precisely in order to maintain soldiers' motivation to participate in it. After a preliminary overview of pre-military academies, I consider how these institutions instantiate these two aspects of the ethics of Israeli militarism in turn, followed by a final section illustrating how they are combined in the theme of purity. 


\section{Israeli pre-military academies: an overview}

The origins of pre-military academies in Israel lie within the national-religious movement. In 1987, the first mechina, B'nei David, was established in the settlement of Eli in the West Bank. The aim was to develop a new path for national-religious soldiers to enter the military, in which they would spend a prior year in religious study preparing for military service (Rosman-Stollman, 2014: 104-107). This programme of informal education was aimed at high school graduates whom the IDF allowed to defer their military service for one year before conscription. ${ }^{4}$ Unlike other pathways that existed, they would then serve a full three-year period in the army throughout its ranks, rather than for a limited time and in specific units (as in the yeshivot hesder programme). Graduates were encouraged to serve in combat roles and to extend their service by becoming commanders and officers. This new model for national-religious participation in the army proved enormously successful. It drew in many students and became attractive to the army, which thereby acquired a new pool of manpower. By 1996 five religious mechinot had been established, sending hundreds of soldiers to the army each year.

Following a decision to expand the programme to secular students, the first non-religious academy, Nachshon, was established in 1996, and was followed by Beit Yisrael (which mixes secular and religious students) and Rabin Academy in 1997. Offering a broader programme of study than the religious academies, with varying degrees of secular and religious content, these new institutions also allowed their students to defer military service before enlisting. They also proved popular and have grown steadily and exponentially ever since. In fact, in recent years the number of secular and mixed academies has outstripped that of the religious academies (see figure 1). From 2004-2012, the secular and mixed academies more than doubled in number. There are currently 24 secular and mixed academies (collectively referred to as general academies, or mechinot claliot), as opposed to 22 "torah-based academies" (mechinot toraniyot). 
This rapid growth in the number of academies has also fuelled an increase in student numbers, a figure which recently topped 3,300, making mechinot the largest pre-army education programme in Israel (Jerusalem Post, 2013; see figure 2). There is currently rough parity between the number of students at religious and secular academies, which means that the national-religious are still over-represented. However, present trends suggest that this balance may continue to shift in the direction of secular and mixed academies. 
Figure 1: Israeli pre-military academies, 1997-2013

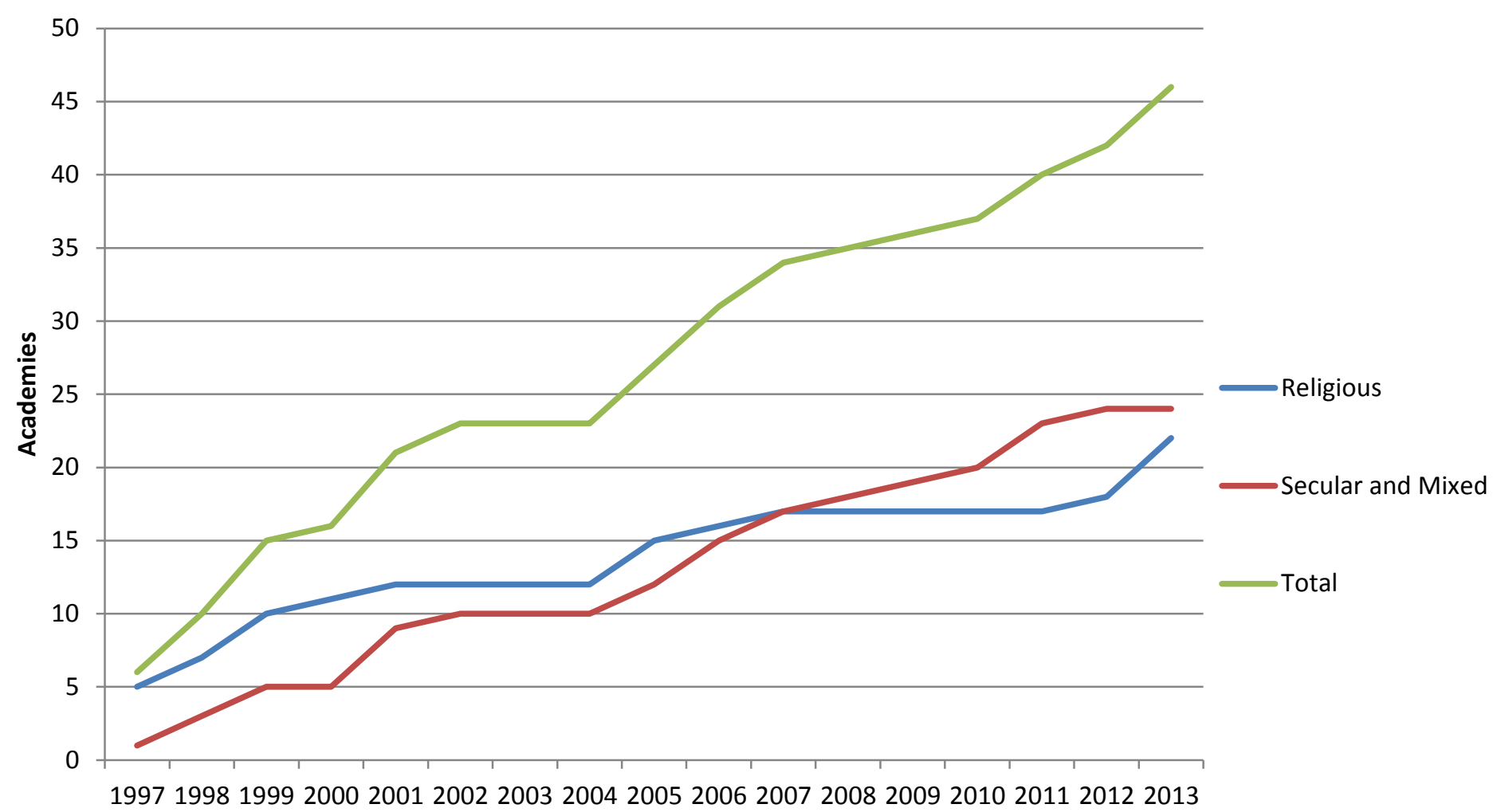

Figure 2: Students at pre-military academies, 1997-2013

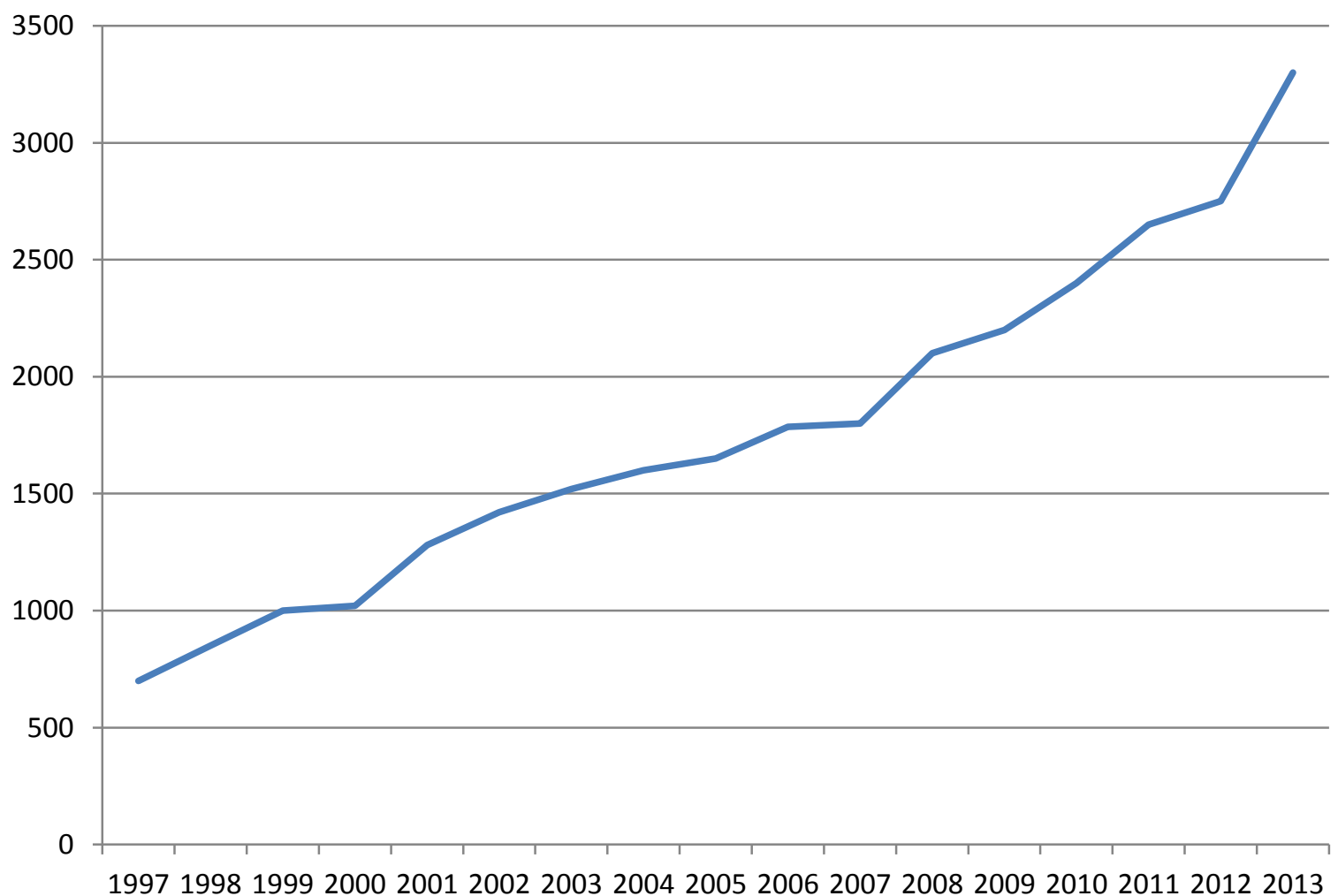

Sources: 1997-2012, Education Ministry Document, 2012 (I am grateful to Yochanan Ben Ya'akov for sharing this with me); 2013, Jerusalem Post. 
As a result, the student body of pre-military academies is now quite diverse. Several religious academies have begun to cater to sections of Israeli society beyond the national-religious. In 2013 a mechina for haredi students was established in a settlement in the Jordan Valley. ${ }^{5}$ There are also religious academies which seek out students from socially disadvantaged groups who have not necessarily had a strong religious upbringing, such as Kiryat Malachi, Tammir, or Maskiyut (Ben-Ya'akov, 2013). ${ }^{6}$ Likewise, the secular and mixed academies have many students besides affluent secular ashkenazim. The army has increasingly become interested in the capacity for academies to deliver extra manpower from "peripheral" groups in society with lower enlistment and higher dropout rates (cf. Levy, 2007: 117-125, 229-236). Accordingly, a number of academies now exist for disadvantaged or "peripheral" youth, including the Jerusalemite Academy, Gal Academy, Yemin Orde (catering for immigrants, and especially for Ethiopians), Kerem-El (aimed at Druze students), and Asher Ruah Bo (Domb, 2012; Ben-Ya'akov, 2013). Mechinot have had a strong impact on the IDF. The rate of enlistment to officer courses is $50 \%$ higher across the board at pre-military academies; and the rate of enlistment to "high priority units" (principally combat units) is also 30\% higher (Education Ministry Document, 2012). This is true in both religious and secular academies. In data gathered from 2001 to 2004, the percentage of eligible male ${ }^{7}$ students from academies who progressed to combat units, to junior command roles, and to the officer corps was measured and later published in an IDF journal (Evenshpenger, 2010). The results are presented below: ${ }^{8}$

Table 1: Median data on military service of graduates of pre-military academies, 2001-2004

\begin{tabular}{|l|l|l|l|}
\hline & $\begin{array}{l}\text { \% entering combat } \\
\text { units }\end{array}$ & $\begin{array}{l}\text { \% entering junior command } \\
\text { roles }\end{array}$ & $\begin{array}{l}\text { \% entering officer } \\
\text { corps }\end{array}$ \\
\hline Religious & 82 & 43 & 16 \\
\hline Secular/mixed & 73 & 40 & 25 \\
\hline
\end{tabular}


These figures demonstrate the effectiveness and success of academies, which I will now seek to explain through an analysis of their pedagogical approach.

\section{Cultivating the self}

If one wishes to grasp the guiding philosophy behind education at pre-military academies, the key concept is "meaningful service" [sherut mashma'uti]. This phrase describes the desired experience which academies want their graduates to have in the IDF: military service which shapes them as individuals, has a lasting impact on their lives, and makes a positive and profound contribution to the work of the army. The concept appears on the website and prospectus of nearly every mechina and is one of the major objectives of the programme. This implies a fusion between the activity of self-improvement and the pursuit of military goals, which become mutually reinforcing objectives. The pathway to effective military service is ethical self-cultivation; likewise, military service is the means to cultivate the soldier as an ethical subject.

When I asked a teacher at Keshet Yehuda, a religious academy in the occupied Golan Heights, to describe what was meant by the phrase "meaningful service", he replied with the following analogy:

“One of the kids was telling me there's a game on television called 'The Golden Cage' or something. The person can go in there and while he's in there he can win prizes... I don't want to compare to that because it's much more than that, actually, when you realise that every minute you have in the army has great importance and meaning. And even if, you know, right now [...] you're doing a very mundane task... every task is not just an individual thing that you're doing but you're doing it for your nation, you're dedicating your time $[\ldots]$ in the most vigour you have in life, when you're young $[\ldots]$ When I say meaningful: that they take advantage of the time, that they see their time there as being, 
you know, a very positive experience and they use it in the right means." (M. Cohen, 2013)

The response of a teacher at a secular academy was similar:

"I guess if you are an Israeli, one thing that I felt when I was in the army, that you wake up when you are 18 and you understand that somebody's sending you to this post in the middle of nowhere. And you understood that for the last 18 years of your life, every night, somebody froze to death on this post. Every night. And it's all around the country. And it's everywhere. And you're saying, wow, I wasn't... I slept fine in bed, you know, I rested. But people did that and now it's my turn. And I want [the students] to know that and I want them to do as best as they can to do that. When it's your turn, do it not whiningly and trying to get away from that and doing as little of it as you can - like most people do, because it's a burden. But take this burden and do it as well as you can." (Shamama, 2013)

Both of these teachers therefore note the connection between national service and ethical effort, suggesting that a powerful link is being forged here between national, civic belonging and individual work in this military rite of passage (cf. Sasson-Levy, 2008; Helman, 1997). Academies make a great effort to facilitate this "meaningful service" by preparing their students for the army. The law requires that a minimum of 8-10 hours a week must consist of preparation for military service, but most academies I visited do more than this. This preparation can take many forms. It might involve visits to particular units and bases to inform students about possible pathways in military service, or talks from serving officers and soldiers. It can also include classes on leadership, battle heritage [moreshet krav], and military ethics. Many academies organise intense physical training, as well as navigation exercises. 
Preparation for "meaningful service" is not confined to these more functional aspects, however. It encompasses the entire programme of study, even where the content is not explicitly military in nature. It entails the promotion of values and a sense of identity among the students as an ideological basis for military participation. At religious academies much of the study is modelled on that of a seminary, including scriptural exegesis, classes from rabbis on questions of faith and morality, collective worship, and everyday religious observance. This is combined with classes designed to deepen Jewish and Zionist identity and to provide "spiritual" preparation for the IDF (B’nei David, 2014; Rosman-Stollman, 2014: 107-114). The teachings of the religious Zionist thinker, Rabbi Tzvi Yehuda Kook, are a very common inspiration for this approach (M. Cohen, 2013; Rosman-Stollman, 2014: 110, 112). These inculcate the idea that earthly pursuits, such as service in the army, can have a redemptive and spiritual function and therefore acquire the character of a religious duty (cf. Aran, 1991: 304-323). Military service is presented as an expression of faith, as an opportunity for drawing and acting on religious values.

This emphasis on values and identity is, however, no less present at secular academies. Although these values derive from different, less religious sources, locating and deepening them is still seen as a crucial aspect of military preparation. Secular academies often describe this as "mental preparation" [hachana mentalit], a term borrowed from military jargon. Staff at several academies emphasised in interviews the need to reverse the influence of "post-modernism" or "globalisation" associated with a decline in the level of civic commitment in society. The director of the Jerusalemite Academy put it as follows:

"I think that the main thing, and I do it from my first lesson, is to ask them what are your values and what do you believe and how what you will do in the army will express your values. And that's a big shock from people because, in our life, in post-modern life... not many people know how to say "what do I believe?" and if I believe in it today, who says 
I'll believe in it tomorrow? So it's very difficult [for] them and we try in a few lessons in all kinds of places to talk about those things.” (Domb, 2012)

The programme of studies at Ein Prat Academy, which is a mixed academy located on a settlement in the West Bank, gives an example of how these mechinot do this. Students are immersed in the study of Western and Jewish philosophy; they read and discuss Plato and Aristotle, as well as modern existentialists such as Kierkegaard, Nietzsche, and Camus. They also study modern Zionist thinkers from Herzl, to Jabotinsky, Kook, and Ben-Gurion. The director of the academy, David Nachman, was clear about the purpose of this study:
"These studies are in order to build the identity of each... Students are coming here because they want to understand their identity as human beings, first of all, like every other place on the planet, and as Jews and as Zionists. That's why we learn Western philosophy, which talks about life, about political philosophy. Judaism is common to all of us - it doesn't matter if you're religious or non-religious. The sources are relevant for all of us. And then Zionist thinking or Zionist thought form the basis. And then when you go to the army then you understand better why do I have to go to the army and which kind of a soldier do I have to be... A Jewish soldier. We are teaching how a Jewish soldier has to act." (Nachman, 2013)

This emphasis creates a strong connection between the task of personal improvement and military performance. Nachman further remarked that "a good soldier is in the beginning a good man", a view echoed by a teacher at a religious pre-military academy (Nachman, 2013; Mass, 2013). This gendered language further suggests that the production of military masculinities is strengthened through this ethical work (cf. Sasson-Levy, 2008).

Academies also build self-cultivation into everyday residential life. At Rabin Academy there is a strong emphasis on what the director refers to as "self-conduct" [nihul atzmi], which involves the 
students learning to manage their own behaviour and abide by the rules and timetable. No alcohol is allowed and the study day is extremely long, beginning at 7am and sometimes lasting until as late as 11 or 12 at night (Zamir, 2012). Other academies have more relaxed rules but place a greater onus on the students themselves to manage daily activities and living arrangements (Domb, 2012). Students at the mechina in Jaffa, Telem, elect weekly student leaders to organise this who are given authority over others (Immerman, 2013). All of these endeavours aim to help students practise for the responsibilities they will be given during military service, and to encourage them to learn to conduct themselves (see also RosmanStollman, 2014: 111).

This emphasis on constant self-improvement in preparation for military service takes a strongly ascetic form, in which students are encouraged to continuously demand more from themselves. Foucault describes asceticism as “... a progression according to a scale of increasing difficulty $[\ldots]$, an exercise going from the easier to the more difficult, and from the more difficult to what is even more difficult" (2008a: 185). This is achieved through constant work of the self on the self, practising and testing oneself to achieve "egoistic self-mastery" (2008a: 207-208). It is not difficult to see how such an emphasis would be useful in a military context. Indeed, it conforms to the model already analysed by Sasson-Levy, in which the pursuit of "self-control" is an important aspect of the masculine identity of Israeli soldiers (2008: 305-309). Rather than the physical and emotional discipline which Sasson-Levy discusses, however, this aspect of military masculinity is presented as moral, even spiritual. Moreover, unlike Sasson-Levy's account of the bodily violence of military training, this control is not imposed externally: the students exercise it over themselves through intense ethical work.

Of all the academies I visited, this ascetic emphasis was particularly pronounced at Ein Prat. This mechina was deliberately built on an outcrop overlooking the mountains of the Judean desert in order to inspire its students and concentrate their minds, giving the whole academy an isolated, 
coenobitic atmosphere. The academy self-consciously reinforces the importance of constantly striving for more from oneself. The director put is as follows: "Our slogan here is that if one does not try all the time to climb up more and more and stays in one place, he falls down. He must all the time try to be better. All the time. This is the way of life here." (Nachman, 2013) Indeed, in my conversation with one student I learnt that students strongly internalise this impetus. He described to me discussions with his peers about how difficult it was to know when to miss a class because of illness, since it was impossible to be sure that their absence was not ultimately down to lack of effort. ${ }^{9}$

This ascetic emphasis also features in education at religious academies and dovetails with religious observance. The most widely-used text to discuss personal morality is Messilat Yesharim ["The Path of the Upright"], an $18^{\text {th }}$ century text by Rabbi Moshe Haim Luzzatto (M. Cohen, 2013). ${ }^{10}$ This text describes the key traits of righteousness and how to acquire them. Notably "watchfulness" [hizhirut] is the first of these qualities, which explicitly encourages selfexamination as a means to separate "the good from the evil" in one's actions (Luzzatto, 1966: 44). Although such judgments are informed by halakha ${ }^{11}$, for Luzzatto self-examination does not simply mean conformity with a minimum standard. Even "good" actions are to be examined for traces of impure motivation, implying a constant struggle for improvement.

This practice of self-invigilation is institutionalised at religious academies. At Keshet Yehuda, for example, a regular slot is allocated in the timetable for "self-examination" [heshbon nefesh] (M. Cohen, 2013). It is also common for soldiers to consult with teachers and rabbis from their mechina during their military service. Rabbis frequently issue responsa based on these inquiries for all students to follow. Indeed, Cohen (2007: 43) has observed that, thanks to information technology, this practice has become widespread through the use of SMS messaging and online forums. During "Operation Protective Edge" ${ }^{12}$, for example, Rabbi Shlomo Aviner of Ateret Cohanim academy posted several rounds of SMS question and answers on his website, with 
topics ranging from dietary matters and fasting, to prayer, to the ethics of killing civilians (e.g. Aviner, 2014a). ${ }^{13}$ It is to the last of these issues, and related matters of military ethics, that I now turn.

\section{Teaching military ethics}

Although religious and secular academies teach military ethics in different ways, drawing on different sources and occasionally reaching divergent conclusions, there are important regularities in their pedagogy. Firstly, it enhances and extends the emphasis on self-conduct that I have already described. However, it also makes a further ideological contribution, which is to legitimate military violence and generate an impression of the IDF as a moral army. To achieve this, academies employ pedagogical strategies designed to moralise and de-politicise questions of violence; at religious academies, techniques of abstraction are also used. I discuss some of these approaches below.

At secular and mixed pre-military academies, military ethics is taught in a variety of settings. It often appears in classes dedicated to life in the army or to leadership (Zamir, 2012; Domb, 2012). Some mechinot offer classes which are specifically dedicated to studying the IDF ethical code (“The Spirit of the IDF") and deal with one of its basic values each week (Berkeley, 2013). Classes on military ethics usually involve discussion of common moral dilemmas which occur during military service; teachers frequently draw on their own military experience to illustrate a certain point or generate discussion. What is notable is that, in teaching military ethics, secular academies rarely shy away from difficult questions or troubling information about the violent reality of Israeli military rule. For example, in one class where I was present, the teacher provided the students with a testimony from a soldier given to the human rights observatory $B^{\prime} T$ selem about bribery and exploitation at checkpoints, evidence which she supported from her own experience. $^{14}$ 
This often leads to extremely heated discussions among the students, who usually have grown up hearing a more sanitised version of events from the Israeli media. I witnessed several such emotional debates. Perhaps the most famous example of this approach was an event held at Rabin Academy in 2009 to discuss several graduates' experiences from "Operation Cast Lead"15 in which soldiers described the killing of unarmed civilians and widespread vandalism (Rabin Academy, 2009). The teachers I interviewed and observed continuously emphasised their belief to me that exposing students to such facts would encourage them to act more ethically, rather than discourage them from serving. One was explicit about this strategy:

“... you even take the slight chance that one of them will say, I don't want to join the army - it's too horrible. Because we show them the horrible sides of that. And there are. If you are in Hebron, it's not nice for you. [...] And they see everything. But we believe it will not make them not want to join the army or be part of the Jewish nation but [...] will help them choose the more moral way." (Shamama, 2013)

One example of this I observed involved a screening and discussion of the film To See If I'm Smiling, which is based on the testimonies of women IDF soldiers about the moral difficulties they faced. ${ }^{16}$ Some of the details are extremely disturbing. The title derives from the moment when one of the veterans looks at a photograph of herself next to a Palestinian corpse with a post-mortem erection - to see if she is smiling. However, in the discussion following, the teacher emphasised his belief that the film was primarily raising moral not political questions about the occupation, questions which the students could learn from in preparing for military service. This approach was also demonstrated to me at a class I witnessed at an academy in Jaffa. ${ }^{17}$ Students were shown a video of soldier violence at Huwara checkpoint by the veterans' anti-occupation organisation Breaking the Silence. In the ensuing discussion, the teacher told the students that he had been posted at this checkpoint in the past and that things had been very different under his command. He encouraged the students to take this video not primarily as evidence of the 
structural violence of the occupation but rather as a source of motivation for them to join the IDF, become leaders, and make a difference in situations such as this.

This pedagogical approach is therefore performing an extremely subtle ideological operation. It does not deny that widespread violence and misdemeanours occur in the IDF. Instead, it carefully marshals this evidence in order to stimulate ethical activity. In the process, questions about the political or structural origins of this violence are elided. As Grassiani has shown, the everyday realities of military occupation make occurrences such as abuse at checkpoints and violence during arrests inevitable (2013: esp. 73-101). Yet students at secular and mixed premilitary academies are instead taught that such problems are primarily individual and moral failings, which can be eliminated through ethical work. Indeed, while these episodes of violence are moralised, they are also simultaneously de-politicised, drawing attention away from the question of occupation and towards the desire to improve individual conduct. This legitimates participation in the institutions which practice this violence by making its occurrence seem contingent and its worst excesses seem tractable.

It is often insinuated that national-religious soldiers have fewer moral qualms about exercising violence than their secular counter-parts. Especially after Operation Cast Lead in 2009, there was growing commentary about the influence that the Military Rabbinate and the rabbis of yeshivot hesder and religious mechinot have over the military. Evidence surfaced of rabbis having given strong encouragement to soldiers to fight before the operation. The unprecedented level of civilian deaths in that operation reinforced the impression that this religious influence had contributed to a relaxed attitude to civilian casualties (see, for example, Harel, 2009; Bronner, 2009). Often cited was the controversial remark made by Rabbi Shlomo Aviner in a text circulated to soldiers before the operation: 
"When you show mercy to a cruel enemy, you are being cruel to pure and honest soldiers. This is terribly immoral. These are not games at the amusement park where sportsmanship teaches one to make concessions. This is a war on murderers. 'A la guerre comme la guerre.' " (quoted in Harel, 2009)

Yet, disturbing as such comments are, they should not be taken as proof of a lack of engagement with questions of military ethics among the national-religious. An analysis of pedagogy at premilitary academies shows that they are in fact deeply concerned with these questions, even if the approach may be different from secular academies.

One major difference in the way religious pre-military academies deal with these issues relates to source material. They devote far less attention to texts such as the IDF ethical code. Instead scripture and halakha are the main authorities. Until recently, the number of religious sources discussing conduct in warfare was very limited. However, as Cohen has observed, accompanying the rise of national-religious soldiers in the IDF, there has been a huge growth in the number of texts by rabbis concerning military ethics which interpret Jewish law in this context (Cohen, 2013: 85-108). Indeed, it is striking that the main discursive innovations required to facilitate the entry of religious soldiers into the IDF have been ethical. The rabbis of religious mechinot have been noticeably involved in this effort, including Rabbi Rafi Peretz (formerly of the mechina in Atzmona, and current IDF Chief Rabbi), Rabbi Shlomo Aviner (principal of the Ateret Cohanim Academy), and Rabbi Eyal Krim (also from Ateret Cohanim) (Cohen, 2007: 43, n. 20). Very often lessons at academies concern how to maintain religious observance on duty, including the observance of dietary laws, keeping the Sabbath, interacting with women, and so on (RosmanStollman, 2014: 113). Yet they also concern conduct towards other soldiers and towards the enemy. 
Indeed, despite his widely publicised comments, Shlomo Aviner has been among the most actively involved in questions of morality in combat. Several of his lessons have dealt with this and have been published online through the Ateret Cohanim yeshiva, where the mechina is based. In one lesson Aviner discusses the question "is it permissible to kill a terrorist who takes shelter behind ordinary people?" (Aviner, 2014b). Discussing concrete examples, including the assault on Jenin in "Operation Defensive Shield", Aviner concludes that it is indeed permissible. He argues that such civilians, even though they may be innocent and without intention to harm, have the status of a rodef, a halakhic term for someone who endangers Jewish life, because he provides shelter for those trying to kill soldiers.

When I asked a teacher at Keshet Yehuda academy about how he dealt with this issue, his conclusion was no different:

"If you are in battle and terrorists are hiding in a house behind a civilian population, even children, and they are shooting at our soldiers and they're being wounded, what would the right reaction be? So some soldiers will tell you we can't shoot because we're going to damage civilians, even children. Is that the right approach or not? So that's a very big decision that has, you know... it's a dilemma, and it depends on obviously the reality in the field. If you can do it in any other way, you should attempt any other way but harming innocent children and civilians, but in reality there's a very basic moral question here. Whose children are more important? Are their children more important, or my children more important? Because those soldiers fighting are our children [...] And I think any sane human being, when his house is being threatened or his children are being threatened, is going to prefer saving his own children.” (M. Cohen, 2013)

Disagreeable as we might find this perspective, it is also clear that it is based on ethical reflection. Indeed, its logic is not dissimilar to that of some secular Israeli military ethicists, who have 
argued that the IDF has higher obligations to its soldiers than to civilians not under its "effective control" (Kasher and Yadlin, 2005). In such cases, the question of the legitimacy of the violence is schematised and moralised in order to make it more palatable, raising the discussion to the level of abstract principles.

This encouragement of abstraction is used to pre-empt and confront the potential difficulties soldiers may have during military service by encouraging them to downplay ambiguities and concentrate on the overall ethical purpose. The teacher at Keshet Yehuda academy described to me how he would do this in class:

“... in the beit midrash [study hall] I can talk to them about... how it can be that [there] are very good people who are moral people who may be amongst the population of our enemy. But when they're in battle and they're facing off these enemies they have to be able to know that... you know, their reactions cannot be dulled by that understanding... When you're facing off a terrorist and he's about to kill you or your friend, you don't try and look for the points of merit within him: you shoot." (M. Cohen, 2013)

In another of his lessons, Shlomo Aviner also emphasises the importance of taking ethical pride in combat:

"A soldier kills a terrorist and afterwards feels bad that he killed a person. Is this bad feeling a sign of a gentleness or imperviousness? Certainly it is a sign of imperviousness... Moral people fight to destroy evil... [The soldier] must be very joyful that he kept this religious duty [mitzvah]." (Aviner, 2014c; my translation)

There are of course distinctive features to the way in which moral qualms are dealt with at religious academies. The moral ambiguities are less pronounced than at secular academies and equivocation is rejected as a sign of weakness. The violence is presented as a battle between 
good and evil, or a struggle against vilified "terrorism". The examples also tend to be more abstract, dwelling far less on the actual details and consequences of violence. Indeed, as Cohn (1987) has argued, the capacity for abstraction in such discussions of violence can make it seem more legitimate.

Despite these differences, however, they all view military ethics absorbed through careful work of the self on the self as an important part of preparation for military service. The outcome is a shared belief among mechinot that the education they offer contributes to the morality of the IDF, even in the face of the colossal violence it exercises. Dani Zamir, director of the secular Rabin academy and chairman of the joint council of mechinot, was adamant about this in interview:

"To tell the truth, I think that the Orthodox mechinot that are very extreme in their view, their political view, of the political solutions, are doing excellent work in the ethical education of their students. For example, there is no one who graduated from Orthodox mechinot or from secular mechinot who have done war crimes or refused to do something. I mean, it's a very successful programme [...] There is more lack of understanding between secular soldiers who went to mechinot and those that went straight from school [...] than between soldiers from secular and Orthodox mechinot." (Zamir, 2012)

Whatever the truth of his claims about "war crimes", most striking is Zamir's conviction that the shared focus on the ethical preparations for warfare is what unites religious and secular academies.

\section{"Purity of arms": military service as a test of the self}

In his closing lectures on "The Hermeneutics of the Subject", Foucault emphasises the importance in classical ethics of "life as a test of the self", in which one's actual conduct becomes the yardstick for the success of the ethical work undertaken through study, self-mastery, 
and self-examination (2005: 486). At Israeli pre-military academies military service is treated precisely as the experience which forms the proper basis for this test. Militarism thereby inheres in the fact that it is participation in war which becomes the most crucial indicator of ethical character. This allows for the combination of the ascetic drive for constant self-improvement discussed earlier with the importance attached to military ethics outlined in the previous section. In this final section I will argue that one crucial idiom through which this combination takes place is the theme of "purity".

In secular academies, the value of "purity of arms" [tohar haneshek] has central importance in discussions of military ethics. "Purity of arms" is perhaps the most emblematic of the values in the ethical code of the IDF. It stipulates that a soldier should only use his or her weapon in selfdefence and should strive as far as possible to reduce harm to civilians. This value is often invoked as the basis for the IDF's claim to be a moral army and therefore has a very significant ideological status. One class I observed on "purity of arms" at a secular academy began with readings from the "Spirit of the IDF" and from the textbook, Military Ethics, written by the philosopher Asa Kasher. ${ }^{18}$ The segment chosen from Kasher's book emphasised how the value of purity of arms relates to all behaviour of a soldier, not just in battle (Kasher, 1996: 52-53). A common interpretation is to generalise the value of purity of arms further into a constant imperative to improve one's behaviour, which of course fits perfectly with an ascetic approach. Reflecting on the formulation of the value in a class I observed, one student commented that he approved of the use of the term "purity": "because [purity] is an extreme, it requires [the soldier] to aspire at all times to be moral [musari]". ${ }^{19}$

This emphasis on purity as a desirable extreme was also present in teaching at another academy. The teacher described to me an example from his own experience serving in the IDF which he uses to generate class discussion: 
“when I was in commanders' course we were called to do some combat emergency stuff. And... It wasn't really combat. We were guarding the [...] Green Line, where a lot of, you know, illegal workers pass every day [...] we were there for like a week or a week and a half and it was quite hard. We were living in tents and we were eating the combat food, which is basically the worst food in the army, and we found... we stopped some people on their way back from illegal work and after, like, sort of checking them and writing their things down and letting them go, one of them forgot a watermelon behind. And then someone from the platoon took the watermelon back to the tent and then we had a huge discussion if we should eat this watermelon for dessert or not. And, so that's a personal example I give the kids to deal with. I, myself, think there's no reason to eat the watermelon. And I say that to the kids in the end but many of them disagree. They think eating the watermelon is fine. Soldiers are working hard and it's been forgotten anyway, it's going to just sit there and rot and whatever." (Berkeley, 2013)

What is striking about this example is its utter remoteness from the usual considerations of collateral damage or civilian casualties. Indeed, it is not immediately obvious how it relates to "purity of arms" at all. The teacher explained:

“...the message behind the value of purity of arms is make sure you don’t turn your authority and your power in being armed into anything extra at all than the security of Israel. The minute there's anything extra, that is not necessary, that's you crossing the line and doing something that I think is immoral. So that's my explanation... It's a sort of silly example but I think because it's sort of silly I think it's quite good because it's sort of like taking it to the extreme." (Berkeley, 2013)

This example illustrates how the value of "purity of arms" is in fact much more about facilitating the ethical self-cultivation of Israeli soldiers than about reducing the level of violence. Indeed, 
the violence of occupation is also rendered acceptable in this example. For the Palestinian who lost a watermelon, the deliberations of Israeli soldiers about whether to eat it are completely immaterial. What actually cost him the watermelon was a regime of confinement and surveillance preventing him from moving freely between home and work. Yet by converting the value of purity of arms into an extreme test of moral character, the structural violence of the Israeli occupation disappears into the background of a constant struggle for the self-cultivation of the soldier.

Occasionally, the insistence on "purity of arms" takes on additional connotations of literal cleanliness. At the discussion at Rabin Academy after Operation Cast Lead in 2009, the topic of conversation which appears to have caused the greatest argument, eclipsing even the question of killing of civilians, was whether to clean the Palestinian houses occupied during the fighting. The director of the academy was adamant that this was a crucial part of being a good soldier, but many disagreed. One graduate referred to his pride in the fact that his unit cleaned a Palestinian house even though it had caused a great deal of resentment among the soldiers. He said that he doubted that the "Syrian" or "Afghan" army would do this, showing how ethics is an important part of distinguishing the IDF in national and ethnic terms as a moral army (Rabin Academy, 2009). Again, in this example the question of actual violence recedes and the discussion focuses on much less consequential questions of personal conduct. In this ethical imaginary, one clean house in a devastated urban landscape stands as testament to "purity of arms".

Although religious pre-military academies do not tend to teach "The Spirit of the IDF" or the value of "purity of arms", the theme of purity nevertheless plays an important role in ethical practice there as well. In the widely-taught text on moral improvement, Messilat Yesharim, this striving for inner purity is a crucial goal. Luzzatto describes the necessity of examining one's actions to this end: 
"If he finds in them the least trace of evil, he should not give himself rest until he thinks of a plan whereby he may depart from it and purify [lehitaher] himself of it... [This] means to investigate even the good actions themselves, in order to find out whether they contain any questionable admixture, or any element of evil that ought to be utterly stamped out... [H]e who wishes to be spiritually pure [zach veneki] must examine his actions with the utmost scrutiny to find out their nature." (Luzzatto, 1966: 46-47, translated adjusted)

The idea of "purity" as an extreme zero-point is very much present in this passage, as it is in the value of "purity of arms". Indeed, purity is a common idea used to describe soldierly virtue. In a lesson entitled "Purity [nekiut] and the Victory of the Army in War", Rabbi Eliazar Castiel of B'nei David academy cites Psalm 18, in which David attributes his military victory to the "cleanliness of my hands", "according to my righteousness" in the eyes of God (Castiel, 2014). Castiel argues that military effectiveness depends on soldiers being "cleaner, purer, more precise" [yoter neki'im, yoter tehuri'im, yoter medakdaki'im] in order to maintain their motivation and the belief that they are doing "the work of God". Following the death of Sgt. Hadar Goldin in Operation Protective Edge, a graduate of B'nei David, a speaker at his memorial service singled out this quality of "purity":

"Our dear Hadar, you know what you were fighting for: not for quiet skies over the South and not for an iron dome ${ }^{20}$ [kipat barzel $]$ or some agreement or another. You were fighting the war of the yarmulke of faith [kipat ha'emuna], the dome of heaven [kipat shamayim], the powers of purity [tahara] against the tunnel dwellers, the cave diggers who do not know the sun's light, who sit in silence and are considered as nothingness." (Channel 10 News, 2014) 
By eulogising Goldin in this way, military participation in Operation Protective Edge - in which over 2,200 Palestinians were killed, many of them in the bombardment of Rafah which took place in the frantic search for Goldin - is constructed as a demonstration of ethical character. Moreover, the trait of purity is almost explicitly racialised in these remarks, through the direct comparison with Hamas fighters in tunnels. This ethical value of purity pursued through ascetic self-cultivation comes to constitute an ethnic and national marker, cementing the ideological belief in the IDF as a moral army.

There are certainly important differences in the way this theme, and its accompanying ethnic and national significance, is broached at secular and religious academies. In religious academies, the "purity" of the soldier is achieved primarily before battle as a way of deepening faith and resolve and is axiomatically contrasted with the perfidiousness of the enemy. Conversely, in secular academies this contrast is more complex, arising from a messier encounter between the soldier and the enemy population. Purity is therefore usually demonstrated during and after battle through acts designed to distinguish Israeli soldiers from the enemy population (in, for example, refusing to eat a watermelon or insisting on cleaning a house). In each case, however, it is around this theme of purity - and of military service as the test and expression of it - that the ascetic emphasis on self-cultivation and the ideological emphasis on military ethics are able to coalesce.

\section{Conclusion}

This article has surveyed the contribution of ethical pedagogy at pre-military academies to Israeli militarism. It has shown the importance of practices of ethical self-cultivation to preparation for military service and analysed the ideological contribution of military ethical pedagogy to the legitimation of violence. The growing prominence of these academies, combined with their wide social reach, suggests that these intersections between ethics and militarism are of increasing significance in way that Israel motivates its soldiers to fight. This evidence is of particular 
significance given Israel's status as a leading contributor to wider global trends in military and security practice. It suggests two specific conclusions which might be taken up as the starting point for research in other contexts.

Firstly, this study indicates possible transformations in the character of militarism. It suggests that militaries such as the IDF are increasingly interested in more than simply the technical capacity of soldiers to perform well on the battlefield (cf. Howell, 2015). They promote a regime of governmentality aimed at the formation of soldiers as ethical subjects who monitor and strive to enhance their conduct and who believe strongly in the righteousness of the army for which they fight. Ethical capacity has been added to physical fitness and battle-readiness as a feature of all-round military preparedness. This fosters a kind of militarism in which what one does during military service becomes a barometer of character; it speaks a truth about the soldier as a subject. Secondly, this study questions the limits of the capacity of ethics to critique violence. It has shown that, even while the colonial violence brought to bear upon Palestine continues to increase, the role of military ethics in Israel has expanded. These developments are not unrelated, I would submit. Throughout this article I have shown examples of the tendency for Israeli military ethics to isolate particular instances of violence, amplify the moral stakes, and yet minimise wider political issues. Instead of raising troubling questions of occupation, colonialism, and racism, such violent moments are re-imagined as struggles between good and evil, as unfortunate or preventable exceptions, or as opportunities to prove individual ethical worth. Ethics can certainly make a powerful contribution to the interrogation of war and violence; but the task of ethical critique must also be to bring these political stakes to the foreground when necessary. Otherwise, ethics clearly risks being subsumed by militarism.

\section{Notes}


${ }^{1}$ Mechina (pl. mechinot) is the short-hand used by Israelis to describe pre-military academies. This term is derived from the verb meaning "to prepare", which underscores their role as conduits for military service.

${ }^{2}$ I visited seven academies between November 2012 and May 2013, directly observed lessons at four, and interviewed staff working at more than a dozen.

${ }^{3}$ An ashkenazi Jew (pl. ashkenazim) is a Jew of European descent.

${ }^{4}$ Under conscription, most Jewish Israelis are drafted into the military at age eighteen, men for three years, women for two.

${ }^{5}$ Haredi refers to ultra-orthodox Jews who have until recently been exempted from military service.

${ }^{6}$ Compare this evidence with Rosman-Stollman (2014: 115), and the assessment of Stuart Cohen: "By definition, [religious mechinot cater] exclusively to a constituency already committed to Orthodox Jewish observance", (2013: 134).

${ }^{7}$ Secular and mixed academies, in contrast to religious academies, are open to both boys and girls. However, there is also a dedicated religious academy for girls.

${ }^{8}$ Although the author of this IDF research expressed doubts about the influence of secular academies, this was mostly based on their small size at the time, which has grown significantly since then (cf. Evenshpenger, 2010: 66).

${ }^{9}$ Field notes, $28^{\text {th }}$ January 2013.

${ }^{10}$ See also the many lessons available on Messilat Yesharim on the website of Ateret Cohanim academy, e.g: https://www.ateret.org.il/hebrew/torah/view.asp?id=1082 [accessed $4^{\text {th }}$ September 2014, Hebrew].

${ }^{11}$ Halakha is the Hebrew term for Jewish religious law.

12 "Operation Protective Edge" was an Israeli military incursion into the Gaza Strip in summer 2014 in which over 2,200 Palestinians and 72 Israelis were killed.

${ }^{13}$ E.g. "Short and Sweet - Text Message Q\&A \#263 - Shut Operation Protective Edge \#3", 4 August 2014, http://www.ravaviner.com/2014/08/short-sweet-text-message-q-263-shut.html [accessed 8th September 2014].

${ }^{14}$ Field notes and copies of hand-outs from the Jerusalemite Academy, $28^{\text {th }}$ January 2013.

15 "Operation Cast Lead" was an Israeli military incursion into the Gaza Strip in December 2008January 2009 in which approximately 1,400 Palestinians and 13 Israelis were killed.

${ }^{16}$ To See If I'm Smiling (dir. Tamar Yarom, 2007); field notes from Rabin Academy, $6^{\text {th }}$ December 2012.

${ }^{17}$ Field notes, $29^{\text {th }}$ November 2012.

${ }^{18}$ Field notes, $28^{\text {th }}$ January 2013 , and copies of the hand-outs used in class.

${ }^{19}$ Field notes, $28^{\text {th }}$ January 2013.

${ }^{20}$ The "Iron Dome" is an advanced missile defence system used during the operation.

\section{References}

Altınay A (2004) The myth of the military nation: militarism, gender, and education in Turkey. New York: Palgrave Macmillan.

Aran G (1991) "Jewish Zionist Fundamentalism: the bloc of the faithful in Israel (Gush Emunim)", in M. Marty and R.S. Appelby (eds) Fundamentalisms Observed. Chicago: University of Chicago Press.

Aviner S (2014a) "Short and Sweet - Text Message Q\&A \#263 - Shut Operation Protective Edge \#3". Available at http://www.ravaviner.com/2014/08/short-sweet-text-message-q263-shut.html [accessed 8th September 2014]. 
Aviner S (2014b) "Is it permissible to kill a terrorist who takes shelter behind ordinary people?", audio recording of lesson given at Ateret Cohanim. Available at:

http://www.ateretmedia.org/ra_sic/ra_sic_741421.mp3, [accessed $5^{\text {th }}$ September 2014, Hebrew]

Aviner S (2014c) "He who is not joyful to kill a terrorist - is he gentle or impervious?", transcript of lesson at Ateret Cohanim. Available at:

https://www.ateret.org.il/hebrew/torah/view.asp?id=1086, [accessed $5^{\text {th }}$ September 2014, Hebrew]

Basham V (2013) War, Identity, and the Liberal State: everyday experiences of the geopolitical in the armed forces. Oxford: Routledge.

Ben-Eliezer U (1998) The making of Israeli militarism. Bloomington: Indiana University Press.

Ben-Ya'akov Y (2013) Education Ministry official, author interview, $30^{\text {th }}$ April, Jerusalem.

Berkeley D (2013) Teacher at Nachshon Academy, author interview, $11^{\text {th }}$ March, Sde Yo'av.

Berghaus P and Cartagena N (2013) "Developing good soldiers: the problem of fragmentation within the army". Journal of Military Ethics $(12,4)$.

B'nei David Academy, Programme of Study. Available at: http://www.bneidavid.org/Web/He/about/Routes/Preparatory/Default.aspx [accessed 2nd September 2014, Hebrew]

Bronner E (2009) “Israel Disputes Soldiers' Accounts of Gaza Abuses", New York Times.

Burchell G (1996) 'Liberal government and techniques of the self' in Barry A, Obsorne T and Rose N (eds) Foucault and Political Reason: Liberalism, Neo-Liberalism, and Rationalities of Government. Chicago: University of Chicago Press.

Carrick D, Connelly J and Robinson P (eds) (2009) Ethics Education for Irregular Warfare. Aldershot: Asghate.

Castiel E (2014) "Purity and the Victory of the Army in War", audio recording of lesson at B'nei David Academy. Available at:

http://www.bneidavid.org/Web/He/VirtualTorah/Lessons/Default.aspx?subject=\&rabi=\&n ame $=\&$ rfs $=\& i d=8168$ [accessed $5^{\text {th }}$ September 2014, Hebrew].

Channel 10 (2014) News item during Operation Protective Edge. Available at: http://www.bneidavid.org/Web/He/VirtualTorah/Lessons/Default.aspx?subject=\&rabi=\&n ame $=\& \mathrm{rfs}=\& \mathrm{id}=8212$ [accessed $5^{\text {th }}$ September 2014, Hebrew with English subtitles].

Cohen M (2013) Teacher at Keshet Yehuda Academy, author interview, $22^{\text {nd }}$ April, Keshet.

Cohen S (2007) "The Quest for a Corpus of Jewish Military Ethics", Journal of Israeli History: Politics, Society, Culture $(26,1)$.

Cohen S (2013) Divine Service? Judaism and Israel's armed forces. Ashgate: Berghahn Books.

Cohn C (1987) "Sex and death in the rational world of defense intellectuals" Signs: Journal of Women in Culture and Society $(12,4)$.

Conway D (2012) Masculinities, Militarisation, and the End Conscription Campaign: War Resistance in Apartheid South Africa. Manchester: Manchester University Press, 2012.

Dalsheim J (2011) Unsettling Gaza: Secular Liberalism, Radical Religion, and the Israeli Settlement Project. Oxford: Oxford University Press.

Dean M (2010) Governmentality: Power and Rule in Modern Society, second edition. London: Sage.

Dillon M and Neal A (eds) (2008) Foucault on Politics, Security, and War. London: Palgrave. Domb Y (2012) Director, Jerusalemite Academy, author interview, $21^{\text {st }}$ November, Jerusalem. Elshtain J (1995) Women and War. Chicago: University of Chicago Press.

Enloe C (2000) Maneuvres: The International Politics of Militarising Women's Lives. Berkeley: University of California Press. 
Enloe C (2007) Globalisation and militarism: feminists make the link. Lanham: Rowman and Littlefield.

Evans B (2010) "Foucault's Legacy: Security, War, and Violence in the $21^{\text {st }}$ century", Security Dialogue (41).

Evenshpenger N (2011) “The mechinot under examination”, Ma'arachot, (336) [Hebrew].

Fassin, D (2012) A Companion to Moral Anthropology. Oxford: Blackwell.

Faubion J (2012) An Anthropology of Ethics. Cambridge: Cambridge University Press.

Foucault M (1979) Discipline and Punish: The Birth of the Prison. London: Penguin.

Foucault M (1980) "The confession of the flesh" in Gordon C (ed), Power/Knowledge: Selected interviews and other writings, 1972-1977, by Michel Foucault. New York: Pantheon Books.

Foucault M (1998) The History of Sexuality, Volume II: The Use of Pleasure. London: Penguin.

Foucault M (2000a) "On the Genealogy of Ethics: an overview of work in progress", in Rabinow P (ed) Essential Works of Foucault, 1954-1984, Volume I: Ethics. London: Penguin.

Foucault M (2000b), "The Ethics of the Concern for the Self as a Practice of Freedom" in Rabinow P (ed) Essential Works of Foucault, 1954-1984, Volume I: Ethics. London: Penguin.

Foucault M (2000c) “Technologies of the self”, in Rabinow P (ed) Essential Works of Foucault, 1954-1984, Volume I: Ethics. London: Penguin.

Foucault M (2002a) “The Subject and Power", in Faubion J (ed) Essential Works of Michel Foucault, 1954-1984, Volume 3: Power. London: Penguin.

Foucault M (2002b) "The Political Technology of Individuals" in Faubion J (ed) Essential Works of Michel Foucault, 1954-1984, Volume 3: Power. London: Penguin.

Foucault M (2005) The Hermeneutics of the Subject: Lectures at the College de France, 1981 1982. London: Picador.

Foucault M (2006) Psychiatric Power: Lectures at the College de France, 1973-1974 London: Palgrave.

Foucault M (2008a) Security, Territory, Population: Lectures at the College de France, 19771978. London: Palgrave.

Foucault M (2008b) The Birth of Biopolitics: Lectures at the College de France, 1978-79. London: Palgrave.

Grassiani E (2013) Solidering Under Occupation: Processes of Numbing Among Israel Soldiers in the Al-Aqsa Intifada. Oxford: Berghahn Books.

Gregory D (2004), The Colonial Present: Afghanistan, Palestine, Iraq. Oxford: Blackwell.

Graham S (2010a) "Laboratories of war: surveillance and US-Israeli collaboration in war and security" in Elia Zureik, David Lyon, and Yasmeen Abu-Laban (ed.), Surveillance and Control in Israel/Palestine: Population, Territory and Power. London: Routledge.

Gordon N (2010) "Israel's Emergence as a Homeland Security Capital," in Zureik E, Lyon D and Abu-Laban Y (eds) Surveillance and Control in Israel/Palestine: Population, Territory and Power. London: Routledge.

Harel A (2009) "IDF rabbinate publication during Gaza war: We will show no mercy on the cruel", Ha'aretz.

Helman S (1997) "Militarism and the construction of community", Journal of Political and Military Sociology (25).

Higate P (2012), “The private militarised and security contractor as geocorporeal actor", International Political Sociology (6).

Hirshkind C (2006) The Ethical Soundscape: Cassette Sermons and Islamic Counterpublics. New York: Columbia University Press. 
Howell A (2015) "Resilience, war, and austerity: the ethics of military enhancement and the politics of data" Security Dialogue $(46,1)$.

Hutchings K (2010) Global Ethics: An Introduction. London: Polity.

Immerman G (2013) Teacher at Telem Academy, author interview, $7^{\text {th }}$ March, Tel Aviv.

Jerusalem Post (2013) "Over 3000 high school students to begin army programmes". Available at: http://www.jpost.com/National-News/Over-3000-high-school-graduates-to-begin-prearmy-programs-324707 [accessed $15^{\text {th }}$ April 2014].

Kasher A (1996) Military Ethics. Tel Aviv: HaUniversita HaMeshuderet [Hebrew].

Kasher A and Yadlin A, "The Military Ethics of Fighting Terror: an Israeli perspective". Journal of Military Ethics $(4,1)$.

Khalili L (2010) "The location of Palestine in global counterinsurgencies". International Journal of Middle East Studies (42, 3).

Kimmerling B (1993) "Patterns of militarism in Israel". European Journal of Sociology $(34,2)$.

Klare M (1980) "Militarism: the issues today" in Eide A and Thee M (eds) Problems of contemporary militarism. London: Croom Helm.

Laidlaw J (2013) The Subject of Virtue: An Anthropology of Ethics and Freedom. Cambridge: Cambridge Univeristy Press.

Lebel (2013) 'Post-modern or conservative? Competing communities over military doctrine. Israeli national-religious soldiers as (counter) strategic agents' in Karakatsanis $\mathrm{N}$ and Swartz J (eds) Political and Military Sociology: An Annual Review (Volume 40).

Levy Y (1997) Trial and Error: Israel's Route from War to De-escalation. Albany: State University of New York Press.

Levy Y (2007) Israel's materialist militarism. Lanham: Lexington Books.

Levy Y (2014) 'The Theocratisation of the Israeli military: a structural analysis', Armed Forces and Society $(40,2)$.

Levy Y, Lomsky-Feder E and Harel N (2007) "From 'obligatory militarism' to 'contractual militarism' - Competing Models of Citizenship”. Israel Studies $(12,1)$.

Lomsky-Feder E and Ben-Ari E (eds) (1999) The military and militarism in Israeli society. Albany: State University of New York Press.

Luzzatto M H (1966) The Path of the Upright. Philadelphia: The Jewish Publication Society of America.

McSorley K (ed) (2013) War and the Body: Militarisation, practice, and experience. Oxford: Routledge.

Mahmood S (2005) The Politics of Piety: The Islamic Revival and the Feminist Subject. Princeton: Princeton University Press.

Maman D, Ben-Ari E and Rosenhek Z (eds) (2001) Military, state, and society in Israel : theoretical \& comparative perspectives. New Brunswick: Transaction Publishers.

Mass R (2013) Teacher at Carmei Hayil Academy, author interview, $23^{\text {rd }}$ April, Beit Rimon.

Morton S and Bygrave S (eds) (2008) Foucault in an Age of Terror: Essays on Biopolitics and the Defence of Society. London: Palgrave, 2008.

Nachman D (2013) Director, Ein Prat Academy, author interview, $28^{\text {th }}$ January, Kfar Adumim.

Owens P (2010) "The ethics of war: critical alternatives" in Bell D (ed) Ethics and World Politics. Oxford: Oxford University Press.

Rabin Academy, "Protocols of the Siah Lohamim of Graduates of Rabin Academy following Operation Cast Lead", printed in Briza, the newsletter of Rabin Academy, March 2009. Available at: http://www.news1.co.il/uploadFiles/384121119976044.pdf [Hebrew, accessed 28th April 2014].

Reid J (2006) The Biopolitics of the War on Terror. Manchester, UK: Manchester University Press. 
Reid J and Dillon M (2009) The Liberal Way of War: Killing to Make Life Live. Oxford: Routledge.

Robinson P, de Lee N and Carrick D (eds) (2008) Ethics Education in the Military. Aldershot: Ashgate.

Rose N (1996) "Governing Advanced Liberal Democracies" in Barry A, Obsorne T and Rose N (eds) Foucault and Political Reason: Liberalism, Neo-Liberalism, and Rationalities of Government. Chicago: University of Chicago Press.

Rose N (1999) Powers of Freedom: Reframing Political Thought. Cambridge: Cambridge University Press.

Rosman-Stollman E (2014) For God and Country? Religious Student-Soldiers in the Israel Defence Forces. Austin: University of Texas Press.

Sasson-Levy O (2002) "Constructing Identities at the Margins: Masculinities and Citizenship in the Israeli Army", The Sociological Quarterly $(43,3)$.

Sasson-Levy O (2003a), "Feminism and military gender practices: Israeli women soldiers in 'masculine' roles", Sociological Inquiry $(73,3)$.

Sasson-Levy O (2003b), "Military, masculinity, and citizenship: tensions and contradictions in the experience of blue-collar workers" Identities: Global Studies in Culture and Power (10, $3)$.

Sasson-Levy O (2008) "Individual bodies, collective state interests: the case of Israeli combat soldiers", Men and Masculinities (10, 3).

Shamama O (2013) Teacher at Lachish Academy, author interview, $20^{\text {th }}$ January, Beit Guvrin.

Shaw M (2013) "Twenty-first century militarism: a historical-sociological framework", Stavrianakis A and Selby J (eds) Militarism and International Relations: Political Economy, Security, Theory. Oxford: Routledge.

Shaw M (1991) Post-Military Society: militarism, demilitarisation, and war at the end of the twentieth century. Temple University Press, 1991.

Segal L (2008) "Gender, war and militarism: making and questioning the links". Feminist Review (88).

Sheffer G and Barak O (eds) (2010) Militarism and Israeli society. Bloomington: Indiana University Press.

Sjoberg L (2006) Gender and the Wars in Iraq: A Feminist Re-Formulation of Just War Theory. Lanham: Rowman and Littlefield.

Sjoberg L and Via S (2010) Gender, War, and Militarism: Feminist Perspectives. Santa Barbara: Praeger.

Stavrianakis A and Selby J (2013) Militarism and International Relations: Political Economy, Security, Theory. Oxford: Routledge.

Wolfendale J (2008) "What is the point of teaching ethics in the military?" in Robinson P, de Lee N and Carrick D (eds) (2008) Ethics Education in the Military. Aldershot: Ashgate.

Zamir D (2012) Director, Rabin Academy, author interview, $6^{\text {th }}$ November, Tiv'on. 